\title{
Field evaluation of some organic and inorganic fertilizers for management of
} Heterodera avenae infecting wheat

\author{
${ }^{1}$ Korayem A.M., M.M.M. Mohamed ${ }^{1}$, M.M.A. Hammam ${ }^{1}$ and S.D. Abou-Hussein ${ }^{2}$
}

IPlant Pathology Department (Nematology Lab), National Research Centre, 33 El Buhouth St., 12622 Dokki, Giza, Egypt.

${ }^{2}$ Agricultural and Biological Research Division, National Research Centre, 33 El Buhouth St., 12622 Dokki, Giza, Egypt.

\author{
Received: 15 March 2020 / Accepted 20 May 2020 / Publication date: 30 May 2020
}

\begin{abstract}
Two field trials were conducted in a wheat farm naturally infested with the wheat cyst nematode Heterodera avenae. The first trial was done to evaluate humic and fulvic acids as organic fertilizers, NPK and ammonium nitrate as inorganic fertilizers for their potential to manage $H$. avenae infecting wheat, in comparison with oxamyl (a chemical nematicide). The second trial was done to evaluate over rates of nitrogen (urea $46 \%$ ) for their suppressive effect against $H$. avenae. Results indicated that all organic and inorganic fertilizers plus oxamyl clearly improved growth parameters of wheat and reduced nematode reproduction, except of NPK treatment. Plant growth and grain yield were greater by fulvic acid and humic acid, as compared with ammonium nitrate and oxamyl. Grain yield weight $/ 1 \mathrm{~m}^{2}$ increased by $37.5 \%, 20.3 \%, 18.8 \%$ and $18.8 \%$ at fulvic acid, humic acid, ammonium nitrate and oxamyl, over control, respectively. The rates of nematode reproduction were reduced by all treatments except of NPK one, they reduced by $23.9 \%, 20.6 \%, 16.0 \%$ and $13.7 \%$ at oxamyl, ammonium nitrate, fulvic acid and humic acid, respectively, however no significant differences between them were detected. Results also showed that all urea rates increased wheat growth parameters and reduced nematode development and reproduction. Greater grain yield $\left(615 \mathrm{~g} / 1 \mathrm{~m}^{2}\right)$ and harvest index $(0.420)$ were obtained at $24 \mathrm{~N}$ rate. All nitrogen rates reduced both the 2-nd stage juveniles in soil 30 days after urea application and the rate of nematode reproduction. Greater reductions in $\mathrm{J}_{2}$ and rate of nematode reproduction $49 \%$ and $40.9 \%$ were occurred at $48 \mathrm{~N}$ rate, respectively.
\end{abstract}

Keywords: Ammonium nitrate, NPK, urea, humic acid, fulvic acid, Heterodera avenae, wheat.

\section{Introduction}

Wheat is the most important cereal crop in Egypt. It is the principal source of bread which form the essential part of Egyptian food of low cost protein, lipids and amino acids. It is cultivated under irrigation, throughout most country but most intensively in Northern and Middle Egypt. The cultivated area was about 1.38 million hectares in 2018 growing season producing about 8.7 million MT (Anonymous, 2018). However, Egypt is the world's largest wheat importer in the world (FOA, 2012). Increasing yield of wheat production is possible through the recognition of phytonematodes affecting wheat productivity and application of suitable methods of their management.

The cereal cyst nematode (Heterodera avenae Woll.) is considered one of the most important nematode pests of wheat in the world (Smiley et al., 2005; Smiley, 2009: Smiley and Nicol, 2009). It has been reported in most countries of Europe and Middle East as well as Australia, Canada, China, India, Japan, New Zealand, Peru, South Africa, USA and countries in North Africa and Western Asia (Meagher, 1977; McDonald and Nicol, 2005; Qiao et al., 2016). The yield losses of wheat due to this nematodes were ranged between $15-92 \%$ depending on nematode density, the environmental factors and sampling protocols (Nicol and Rivoal 2008; Smiley and Nicol, 2009). The annual loss was equivalent to 70 US\$ million in Australia, 4.5 US\$ million in Europe, 9.6 US\$ million in India (CAP International, 1999), and 3.4 US\$ million in the Pacific Northwest region of USA (Smiely, 2009).

In Egypt $H$. avenae was first reported on wheat in Beheira province, northwest Egypt (Ibrahim et al., 1986), Recently $H$. avenae was detected on wheat in Ismailia province northeast Egypt causing loss in grain yield estimated by $40 \%$ at initial nematode population density of $20 \mathrm{~J}_{2} / 1 \mathrm{~m} 1$ soil in pot

Corresponding Author: Korayem A.M., Plant Pathology Department (Nematology Lab), National Research Centre, 33 El Buhouth St., 12622 Dokki, Giza, Egypt. 
experiment (Baklawa et al., 2012), and by $21.6 \%$ at $7 \mathrm{~J}_{2} / 1 \mathrm{~g}$ soil under natural infestation (Korayem and Mohamed, 2015).

Accordingly, controlling of this nematode is of considerable importance to improve the production and livelihood of the farming communities, especially in cropping system frequently suffer moisture or draught stress (Yadav et al., 2002). Strategies that have been used to manage cereal cyst nematodes include chemicals, cultivar resistance, biological control and cultural practices.

The use of chemical nematicides provided effective control against the cereal cyst nematode in many wheat-growing regions of the world especially under severe infestation conditions (Gurner et al., 1980; Brown, 1982; Shahina and Maqbool 1991; Dababat et al., 2015b). However, in the present day the cost and environmental concerns associated with these chemicals do not make them a realist economic option for most wheat growers (Dababat and Fourie, 2018).

Cultivar resistance is considered one of the best means for controlling phytonematodes, it requires no additional equipments or cost. It has been utilized on farms in some wheat-growing areas (Rivoal and Nicol, 2009; Smiley et al., 2013; Dababat et al., 2014; Cui et al., 2016; Pariyar et al., 2016b), but resistant cultivars are not always available. Besides applying of these cultivars needs an accurate knowledge of the virulence spectrum of the target nematode species and pathotypes since the cereal cyst nematodes have a number of pathotypes and intraspecific forms (Andersen and Andersen, 1982; Riggs and Schmitt, 1988; Müller, 1992). So the presence of mixture of parasitic phenotypes in the cereal cyst nematodes adversely affect the use of resistant cultivars and reduce their longevity (Riggs and Schuster, 1998). Moreover the use of resistance, especially derived from single dominant gene may cause disequilibrium in biological communities and possibly ecological replacement with other nematodes such as Pratylenchu s(Lasserre et al., 1994; Turner and Rowe, 2006).

The use of biological antagonists for controlling cyst nematodes is still considered promising method. Nematophagous fungi such as Nematophthora gynophila Trichoderma longibrachiatum and pochonia chlamydosporium were found to be effective for cyst nematode management (Kerry et al., 1982b; Ismail et al., 2001; Holgado and Crump, 2003; Zhang et al. 2014; Baheti et al., 2017). However the use of these antagonists for cyst nematode management has never been commercially feasible .Biological control is an environmentally sensitive, and its ultimate use relies greatly on the agroecology of the cropping systems for persistence and effectiveness (Nicol and Rivoal, 2008). Also it is difficult to generate nematode-suppressive soils to control the cereal cyst nematode populations under economic damage thresholds (Dababat and Fourie, 2018).

Culture practices represent efficient methods in managing H.avenae and may be for other cyst nematodes. They include crop rotation clean fallow, summer ploughing and application of organic and inorganic soil amendments. The crop rotation is considered a good management tactic in terms of effectiveness and economics. Use of grass-free rotations using non-host crops or resistant cultivars are very useful for keeping H.avenae population below damaging levels. (Handa et al., 1976; Fisher and Hancock, 1991; Nombela et al., 1998; Elkcioglu et al., 2004), but the effectiveness depends on the population density, ecological factors and the percentage of non host in the rotation. Besides, in many areas, rotation is not acceptable by growers because the alternate crops are not a profitable or because they require changes in machinery or practices that make them more expensive to grow (Riggs and Schuster, 1998). Deep ploughings during host summer months can reduce population densities of wheat cyst nematodes (Mathur et al., 1987), but it is not always economically and environmentally sound (Dababat et al., 2015b). Addition of soil amendments such as organic and inorganic fertilizers may be a good alternative strategy for managing phytonematodes and increasing the crop productivity. Effect of these fertilizers on nematode reproduction and the plant growth has been reported by many investigators (Swarup, 1986; Brown, 1987; Mathur et al., 1991; Sharma and Khan 1995; Akhtar et al., 1998; Maareg et al., 2000; Trifonova, 2001; Kheir et al., 2009; Farahat et al., 2010; Jothi and Poornima, 2017). The objective of the present research, was to evaluate some of organic and inorganic fertilizers as alternative methods for managing the wheat cyst nematode Heterodera avenae and their effect on wheat productivity under field condition.

\section{Materials and Methods}

Two experiments were conducted in a farm of loamy sand texture naturally infested with the cereal cyst nematode, Heterodera avenae, located in the $6^{\text {th }}$ October Farm at Ismailia Province, Egypt. The farm is irrigated by central Pivot irrigation system. The first experiment was conducted to study 
the effect of some organic and chemical fertilizers, compared to a nematicide (oxamyl 24\% L) on the nematode reproduction and wheat growth parameters. Area of the experiment was divided into three main plots of $60 \mathrm{~m}^{2}$. Each main plot was also divided into six micro plots of $10 \mathrm{~m}^{2}$ each. Three soil samples was obtained from each micro plot, and processed for H.avenae cysts analysis, according to method of Shephered (1970). Ten cysts were squashed according to method of Senihorst and Den Ouden (1966), and the total number of eggs + juveniles $\left(\mathrm{J}_{2}\right)$ per cyst was counted. In 20-11-2018 seeds of wheat (Tritucum aestivum L) cv. Misr-1 were planted. About 50 days after seed germination (in 10-1-2019) each main plot separately received six treatments as follows:

1- Humic acid at rate of $0.65 \mathrm{~g} / 1 \mathrm{~m}^{2}$

2- Fulvic acid at rate of $0.65 \mathrm{~g} / 1 \mathrm{~m}^{2}$

3- Ammonium nitrate $(33.5 \% \mathrm{~N})$ at rate of $66 \mathrm{~g} / 1 \mathrm{~m}^{2}$

4- NPK (20-20-20) at rate of $0.6 \mathrm{~m} 1 / 1 \mathrm{~m}^{2}$

5- Oxamyl (Vydate $24 \%$ ) at rate of $6.0 \mathrm{~m} / 1 \mathrm{~L}$ water

6- Control (without treatments).

Humic and fulvic acids, NPK and oxamyl were dissolved in water and applied as foliar spraying, except of ammonium nitrate was applied as manual application. All treatments were arranged in a randomized block design. Shortly before harvest (in 20-4-2019) a composed sample was obtained from each replicate (micro plot) and processed for cyst analysis as previously mentioned.

The second experiment was carried out to evaluate different rates from nitrogen in the form of urea $(46 \% \mathrm{~N})$ for their suppressive effect against H.avenae reproduction and wheat productivity. The land was divided into three main plots of $50 \mathrm{~m}^{2}$, each one was divided into five microplots of $10 \mathrm{~m}^{2}$. Seeds of wheat cv. Misr-1 were planted in 1-12-2018. About 35 days after seed germination and before treatments (in 13-1-2019) a composed soil and root sample was collected from each microplot to assay the nematode initial population $(\mathrm{Pi})$ : the second stage juveniles. Then each main plot separately received the following nitrogen rates: $0,12,24,36$ and $48 \mathrm{~g} \mathrm{~N} / 1 \mathrm{~m}^{2}$. Treatments were arranged in randomized block design with three replicates.

About 30 days after nitrogen application (in 12-2-2019), soil and root samples were collected from each replicate to assay the nematode population $\left(\mathrm{J}_{2}\right)$ in soil and roots. Juveniles were extracted from soil according to Christe and Perry (1951), and from roots by warring blender. At harvest (5-52019) a composed soil samples were collected from each replicate and processed for cyst analysis. Cysts were extracted from soils and their content from eggs $+J_{2}$ were counted as previously mentioned.

\section{Wheat growth parameters and yield:}

At harvest the plant growth i.e. plant length $(\mathrm{cm})$, weight of grain yield/ spike, grain yield per $1 \mathrm{~m}^{2}$, dry straw yield $\left(\mathrm{g} / \mathrm{m}^{2}\right)$ were determined. The harvest index $(\mathrm{HI})$ of treatments (the grain weight / total weight of grain + dry straw) was also calculated.

\section{Statistical analysis:}

Data from each experiment were subjected to analysis of variance (ANOVA), using SPSS statistical software. Comparison of means was done by use of Duncan's Multiple Range Test at 5\% probability level.

\section{Results}

\section{Effect of fertilizers on wheat growth parameters:}

Effect of organic, inorganic fertilizers and oxamyl on wheat growth and yield is presented in Table (1). Data indicated that all treatments significantly increased growth and yield except of NPK treatment compared with control. Greater plant length and grain yield/spike were obtained by fulvic acid treatment $(85.4 \mathrm{~cm}$ and $1.60 \mathrm{~g})$ followed by humic acid $(81.6 \mathrm{~cm}$ and $1.49 \mathrm{~g})$, ammonium nitrate $(81.2 \mathrm{~cm}$ and $1.45 \mathrm{~g})$ and oxamyl $(80.0 \mathrm{~cm}$ and $1.45 \mathrm{~g})$, with corresponding increase over control of $13.9 \%$ and $18.5 \%, 8.8 \%$ and $10.4 \%, 8.3 \%$ and $7.4 \%, 6.7 \%$ and $7.4 \%$ respectively. Greater weight of grain yield $/ 1 \mathrm{~m}^{2}$ was occurred also at fulvic acid $(440 \mathrm{~g})$ followed by humic acid $(410 \mathrm{~g})$, and both of 
ammonium nitrate and oxamyl (380g), with corresponding \% increase over control of 37.5\%, 28.1\%, $18.8 \%$ and $18.8 \%$ respectively. Same trend was also observed in case of the weight of dry straw and harvest index (HI). Greater \% increases in dry straw weight and HI (17.1\% and 0.50$)$ were obtained by fulvic acid followed by humic acid (12.0\% and 0.49$)$, ammonium nitrate $(9.3 \%$ and 0.48$)$ and oxamyl $(8.0 \%$ and 0.48$)$, respectively compared to control. It was also observed that grain yield $/ 1 \mathrm{~m}^{2}$ occurred at ammonium nitrate and oxamyl were equal.

Table 1: Effect of organic and chemical fertilizers and Oxamyl on growth and yield of wheat naturally infected with Heterodera avenae.

\begin{tabular}{|c|c|c|c|c|c|c|c|c|c|}
\hline Treatments & $\begin{array}{c}\text { Plant } \\
\text { height } \\
\text { (cm) }\end{array}$ & $\begin{array}{l}\text { Inc. } \\
(\%)\end{array}$ & $\begin{array}{c}\text { Grain } \\
\text { yield per } \\
\text { spike (g) }\end{array}$ & $\begin{array}{l}\text { Inc. } \\
(\%)\end{array}$ & $\begin{array}{l}\text { Grain } \\
\text { yield } \\
(\mathrm{g}) / \mathbf{m}^{2}\end{array}$ & $\begin{array}{c}\text { Inc. } \\
\%\end{array}$ & $\begin{array}{c}\text { Dry } \\
\text { straw } \\
\left(\mathrm{g} / \mathbf{1} \mathbf{m}^{2}\right)\end{array}$ & $\begin{array}{c}\text { Inc. } \\
\%\end{array}$ & HI \\
\hline Ammonium nitrate & $81.2 b$ & 8.3 & $1.45 \mathrm{~b}$ & 7.4 & $575 b$ & 19.8 & $615 b$ & 9.8 & 0.48 \\
\hline Humic acid & $81.6 b$ & 8.8 & $1.49 \mathrm{ab}$ & 10.4 & $600 \mathrm{a}$ & 25.0 & $620 \mathrm{a}$ & 10.7 & 0.49 \\
\hline Fulvic acid & $85.4 \mathrm{a}$ & 13.9 & $1.60 \mathrm{a}$ & 18.5 & $615 \mathrm{a}$ & 28.1 & $605 a$ & 8.0 & 0.50 \\
\hline Control & 75.0 & - & $1.35 \mathrm{c}$ & - & $480 \mathrm{c}$ & - & $560 \mathrm{c}$ & - & 0.46 \\
\hline
\end{tabular}

Data are average of three replicates.

Inc.: \% increase over control.

HI: Harvest index (grain yield / total grain yield + dry straw)

Means in a column followed by the same letter are not significantly different according to Duncan's New Multiple Rang Test $(\mathrm{P}<0.05)$

Effect of fertilizers on $\boldsymbol{H}$. avenae reproduction:

Effect of organic and inorganic fertilizers and oxamyl on nematode reproduction is presented in Table (2). A significant reductions in both nematode final population (no. cysts in soil at harvest) and rate of reproduction $(\mathrm{Pf} / \mathrm{Pi})$ were obtained by all treatments except of NPK, compared with control. Greater reduction in nematode final population (27.3\%) occurred at oxamyl treatment followed by ammonium nitrate (19.2\%), humic acid (17.3\%) and fulvic acid (15.4\%) compared to control. Minimum rate of reproduction occurred at oxamyl (2.33) followed by ammonium nitrate (2.43), fulvic acid (2.57) and humic acid (2.64), with corresponding reduction of $23.9 \%, 20.6 \%, 16.0 \%$ and $13.7 \%$, respectively compared to control. However no significant differences in the nematode final population and reproduction were found between them.

Table 2: Effect of organic and chemical fertilizers and oxamyl on $H$. avenae reproduction

\begin{tabular}{|c|c|c|c|c|c|}
\hline \multirow[b]{2}{*}{ Treatments } & \multicolumn{3}{|c|}{ Nematode population } & \multirow[b]{2}{*}{$\begin{array}{c}\text { Rate of reproduction } \\
(\mathbf{P f} / \mathbf{P i})\end{array}$} & \multirow{2}{*}{$\begin{array}{c}\text { Decrease/ } \\
\text { increase ove } \\
\text { control } \\
(\%)\end{array}$} \\
\hline & $\mathbf{P i}$ & Pf & $\begin{array}{c}\text { Increase/decrease } \\
\text { over control } \\
(\%)\end{array}$ & & \\
\hline NPK & 9.8 & $27.0 \mathrm{a}$ & +3.8 & $3.21 \mathrm{a}$ & +4.9 \\
\hline Ammonium nitrate & 10.1 & $21.0 \mathrm{~b}$ & -19.2 & $2.43 \mathrm{~b}$ & -20.6 \\
\hline Humic acid & 9.5 & $21.5 b$ & -17.3 & $2.64 \mathrm{~b}$ & -13.7 \\
\hline Fulvic acid & 10.0 & $22.0 \mathrm{~b}$ & -15.4 & $2.57 \mathrm{~b}$ & -16.0 \\
\hline Oxamyl & 10.0 & $20.0 \mathrm{~b}$ & -27.3 & $2.33 \mathrm{~b}$ & -23.9 \\
\hline Control & 9.9 & $26.0 \mathrm{a}$ & - & $3.06 \mathrm{a}$ & - \\
\hline
\end{tabular}

Data are average of three replicates.

Pi: nematode initial population (no. cysts $/ 100 \mathrm{~g}$ soil) before planting, each cyst contained 60 eggs $+\mathrm{J}_{2}$ in average.

Pf: nematode final population (no. cysts / 100g soil) at harvest, each cyst contained 70 eggs $+\mathrm{j}_{2}$ in average.

\section{Effect of over rates from nitrogen (urea) on wheat growth parameters:}

Data presented in Table (3) showed that all nitrogen rates significantly increased the length of wheat plants, compared to control (zero N). The plant length increased with increasing $\mathrm{N}$ rates, as greater plant length $(64.0 \mathrm{~cm})$ was obtained by $48 \mathrm{~N}$ rate, and the lowest $(57.6 \mathrm{~cm})$ occurred at zero $\mathrm{N}$ (control). Data also indicated that all $\mathrm{N}$ rates significantly increased both grain yield per spike and grain yield $/ 1 \mathrm{~m}^{2}$ compared to control. Greater $\%$ increases in the grain/spike and grain yield $/ 1 \mathrm{~m}^{2}$ $(23.3 \%$ and $20.55 \%)$ occurred at $24 \mathrm{~N}$ rate, respectively. The dry straw also increased with increasing 
$\mathrm{N}$ rates, as greater dry straw $(890 \mathrm{~g})$ occurred at $48 \mathrm{~N}$ dose, and lesser one $(700 \mathrm{~g})$ occurred at zero rate , however, greater $\mathrm{HI}(0.42)$ occurred only at $24 \mathrm{~N}$ dose and lesser $\mathrm{HI}(0.40)$ occurred at the greater $\mathrm{N}$ rate $(48 \mathrm{~N})$.

Table 3: Effect of over nitrogen rates on wheat growth parameters

\begin{tabular}{cccccccccc}
\hline $\begin{array}{c}\text { Nitrogen } \\
\text { rates } \\
\left(\mathbf{g} / \mathbf{1} \mathbf{m}^{\mathbf{2}}\right)\end{array}$ & $\begin{array}{c}\text { Plant } \\
\text { height } \\
\mathbf{( c m )}\end{array}$ & $\begin{array}{c}\text { Inc. } \\
\mathbf{( \% )}\end{array}$ & $\begin{array}{c}\text { Grain } \\
\text { yield } \\
\text { per } \\
\text { spike } \\
\mathbf{( g )}\end{array}$ & $\begin{array}{c}\text { Inc. } \\
\mathbf{( \% )}\end{array}$ & $\begin{array}{c}\text { Grain } \\
\text { yield } \\
\left(\mathbf{g} / \mathbf{m}^{\mathbf{2}}\right)\end{array}$ & $\begin{array}{c}\text { Inc. } \\
\mathbf{( \% )}\end{array}$ & $\begin{array}{c}\text { Dry } \\
\text { straw } \\
\left(\mathbf{g} / \mathbf{1} \mathbf{m}^{\mathbf{2}}\right)\end{array}$ & $\begin{array}{c}\text { Inc. } \\
\mathbf{( \% )}\end{array}$ & HI \\
\hline $\mathbf{0}$ & $57.6 \mathrm{c}$ & - & $1.20 \mathrm{c}$ & - & $490 \mathrm{c}$ & - & $700 \mathrm{~b}$ & - & 0.411 \\
$\mathbf{1 2}$ & $62.0 \mathrm{~b}$ & 7.6 & $1.35 \mathrm{~b}$ & 12.5 & $607 \mathrm{a}$ & 19.56 & $850 \mathrm{a}$ & 21.4 & 0.415 \\
$\mathbf{2 4}$ & $62.5 \mathrm{~b}$ & 8.5 & $1.48 \mathrm{a}$ & 23.3 & $615 \mathrm{a}$ & 20.55 & $855 \mathrm{a}$ & 22.1 & 0.420 \\
$\mathbf{3 6}$ & $62.9 \mathrm{~b}$ & 9.2 & $1.47 \mathrm{a}$ & 22.5 & $608 \mathrm{a}$ & 20.16 & $860 \mathrm{a}$ & 22.9 & 0.414 \\
$\mathbf{4 8}$ & $64.0 \mathrm{a}$ & 11.1 & $1.36 \mathrm{~b}$ & 13.3 & $595 \mathrm{~b}$ & 19.96 & $890 \mathrm{a}$ & 27.1 & 0.400 \\
\hline
\end{tabular}

Data are average of three replicates.

Means in a column followed by the same letter are not significantly different according to Duncan's New Multiple Rang Test $(\mathrm{P}<0.05)$

Inc.: \% increase over control.

HI: Harvest index (grain yield / total grain yield + dry straw)

\section{Effect over nitrogen rates on H.avenae infestation and reproduction:}

Data presented in Table (4) showed that population and reproduction decreased with increasing $\mathrm{N}$ rate. A significant reduction in number of juveniles $\left(\mathrm{J}_{2}\right)$ in soil after 30 days from urea application occurred at all $\mathrm{N}$ rates, compared to control (zero N). Greater reduction in $\mathrm{J}_{2}(49 \%)$ occurred at high $48 \mathrm{~N}$ rate , and lesser reduction (28\%) occurred at $12 \mathrm{~N}$ rate. Also significant reductions in the nematode final population (no. cysts in soil at harvest) occurred at all $\mathrm{N}$ rates compared to control as greater reduction $(40.0 \%)$ occurred at $48 \mathrm{~N}$ rate, followed by $(37.1 \%)$ at $36 \mathrm{~N}$ rate, $34.3 \%$ at $24 \mathrm{~N}$ rate and $31.4 \%$ at $12 \mathrm{~N}$ rate. Rate of nematode reproduction also significantly decreased by all $\mathrm{N}$ rates compared to control, it was $1.91,2.03,2.30$ and 2.40 at $48,36,24$ and $12 \mathrm{~N}$ rates respectively with corresponding $\%$ reduction of $40.9 \%, 37.2 \%, 28.8 \%$ and $25.7 \%$, respectively.

Table 4: Effect of over nitrogen doses on the wheat cyst nematode H.avenae reproduction.

\begin{tabular}{cccccccc}
\hline $\begin{array}{c}\text { Nitrogen } \\
\text { rate } \\
\left(\mathbf{g} / \mathbf{1} \mathbf{m}^{\mathbf{2}}\right)\end{array}$ & $\mathbf{P i}$ & $\mathbf{J}_{\mathbf{2}}$ & $\begin{array}{c}\text { Reduction } \\
\mathbf{( \% )}\end{array}$ & $\mathbf{P f}$ & $\begin{array}{c}\text { Reduction } \\
(\mathbf{\%})\end{array}$ & $\begin{array}{c}\text { Rate of } \\
\text { reproduction } \\
(\mathbf{P f} / \mathbf{P i})\end{array}$ & $\begin{array}{c}\text { Reduction } \\
\mathbf{( \% )}\end{array}$ \\
\hline $\mathbf{0}$ & 650 & $100 \mathrm{a}$ & - & $35 \mathrm{a}$ & - & $3.23 \mathrm{a}$ & - \\
$\mathbf{1 2}$ & 600 & $72 \mathrm{~b}$ & 28 & $24 \mathrm{~b}$ & 31.4 & $2.40 \mathrm{~b}$ & 25.7 \\
$\mathbf{2 4}$ & 660 & $60 \mathrm{~b}$ & 40 & $23 \mathrm{~b}$ & 34.3 & $2.30 \mathrm{~b}$ & 28.8 \\
$\mathbf{3 6}$ & 650 & $52 \mathrm{~b}$ & 48 & $22 \mathrm{~b}$ & 37.1 & $2.03 \mathrm{~b}$ & 37.2 \\
$\mathbf{4 8}$ & 660 & $51 \mathrm{~b}$ & 49 & $21 \mathrm{~b}$ & 40.0 & $1.91 \mathrm{~b}$ & 40.9 \\
\hline
\end{tabular}

Data are average of three replicates.

Pi: initial nematode population $\left(\mathrm{J}_{2} / 100 \mathrm{~g}\right.$ soil $)$ before planting,

$\mathbf{J}_{2}$ : number of juveniles in $100 \mathrm{~g}$ soil, 30 days after nitrogen application.

Pf: nematode final population (no. cysts / 100g soil) at harvest, each cyst contained 60 eggs $+\mathrm{j}_{2}$.

\section{Discussion}

Effects of humic acid and fulive aicd as organic fertilizers, ammonium nitrate and NPK as inorganic fertilizers on the growth parameters of wheat infected with the cereal cyst nematode H.avenae compared to oxamyl (a chemical nematicide) were studied under field conditions. Our results showed that all fertilizers improved wheat growth parameters and diminished nematode reproduction except of NPK one. Greater increases in wheat growth parameters were obtained by fulvic and huic acids, and lesser ones occurred at ammonium nitrate and oxamyl treatmetns. The beneficial effects of fulvic and humic acids on wheat growth may be attributed to their positive and important role in plant nutrition balance. Sangeetha et al., (2006) reported that humic materials have two direct and indirect effects on physiological and biochemical processes in plant and on physical, chemical and biological properties of soil. These beneficial effects of humic substances on plant 
growth have been well documented by many investigators, including stimulation of plant metabolism, increased enzyme activity, increased bioavailability and uptake of nutrients (Mylonas and McCants, 1980; Xudan 1986; Yu et al., 1998; Mackowiak et al., 2001; Atiyeh, 2002; Dursun et al., 2002; Nardi et al., 2002 \& 2009; Serenella et al, 2002; Pilanal and Kaplan 2003; Chen et al. 2004; Turkmen, 2004; Jifon and Lester, 2009 Ye et al., 2009; Hartz and Bottoms, 2010; Parandian and Samavat 2012; Canellas and Olivares, 2014; Priya et al., 2014; Canellas et al., 2015; D'Addabbo et al., 2019).

$H$. avenae reproduction was also inhibited by applying humic and fulvic acids. The inhibitory effect of humic substances against plant parasitic nematodes has been reported by many investigators (Daneel et al., 2000; McBride et al., 2000; Saravanapriya and Subramanian, 2007; Jothi and Poornima 2017; Seenivasan and Senthilnathan, 2018).

The nematicidal efficacy of both fulvic and humic acids could be due to active compounds present in them such as carboxyl and phenolic compounds which are toxic to nematodes (Chitwood, 2002). Moreover, humic substances were classified as biostimulants, fertilizing, plant defence enhancement, increase of soil beneficial microflora, and as inducer of systemic resistance of plants (Sun et al., 2004; Yildirim, 2007; El-Ghamry et al., 2009; Cordeiro et al., 2011; Ibrahim et al., 2013; D'Addabbo et al., 2019). It means that antioxidants such as superoxide dismutase, catalase, reactive oxygen species and ascorbic acid in plant treated with humic substances be increased, these antioxidants may play an indirect role in nematode suppression (Arrigoni et al., 1979; Hassan, 1999; Korayem et al., 2012).

Application of different rates of urea (46\%) improved wheat growth parameters and suppressed nematode reproduction. The dual effect of urea in improving plant growth and suppressing nematode infestation has been documented by many investigators (Rodriguez-kabana and king, 1980; Huebner et al., 1983; Mathur et al., 1991; Trifonova, 2001; Agu, 2002; Bamel et al., 2003; Moussa et al., 2006; El-Sherif et al., 2008; Ismail and Mohamed, 2012; Wei et al., 2012; Al-Hazmi and Dawabah, 2014; Osman et al. 2014). Suppression effect of urea against plant parasitic nematodes may be due to the compound is readly converted to ammonia by urease present in soil, a necessary conversion if urea is to be effective both as fertilizer and as a nematicide(Mojtaedi and Lownsbery, 1976; Huebner et al., 1983; Rodriguez-Kabana, 1986). Urea is a good nematicide when applied at levels in excess of $300 \mathrm{~kg}$ $\mathrm{N} /$ ha. However high levels of urea result in accumulation of nitrite in soil such compound is toxic to nematodes and plants at high levels of accumulation.

The integration of different methods for managing the cereal cyst nematodes was archived by many investigators (Handa et al., 1975; Trudgill, 1987; Mangat et al., 1988; Mathur et al., 1991; Pankaj et al., 2002). They reported that integration between cultural practices (such as summer ploughing, crop rotation, nitrogen fertilizers and chemical nematicides has given promising results for increasing crop yield and reducing nematode population. True integration of different controlling measures as nematicides, organic manures, nitrogenous fertilizers, biological antagonists and crop rotation including non-host plants or resistant cultivars, may be the best strategy for keeping nematode population densities under economic damage (Trudgill et al., 1992).

\section{Conclusion}

The wheat cyst nematode $H$. avenae is considered one of the most important nematode pathogen of wheat causing serious losses in the yield. So its control is of great importance, especially in the countries which wheat is often one of the major food staple. These nematodes present difficult problems in their management, since adult females lay down the eggs inside their bodies which upon death become cysts of hard protective wall. The eggs inside cysts may remain quiescent for many years. Also these nematodes are variable within species, and may undergo antibiosis to aid in their survival in the absence of their hosts. Good management strategy should be aimed at decreasing and maintain nematode population densities under economic damage and must be effective over a period of years or usable year after year. The present results give an approach to control the wheat cyst nematode H.avenae using organic ferlilizers (humic and fulvic acids) that are safer than nematicides. These results should be considered when designing an integrated nematode management program for wheat cyst nematodes. 


\section{References}

Agu, C.M., 2002. Effect of urea fertilizers on root-gall disease of Meloidogyne javanica in soybean, Glycine maxL. Merril. Journal of Sustainable Agric., 20(3): 95-100.

Akhtar, M., Z.A. Siddiqui and I. Mahmood, 1998. Management of Meloidogyne incognita in tomato by some inorganic fertilizers. Nemat. Medit., 26(1):23-25.

Al-Hazmi, A.S. and A.A.M. Dawabah, 2014. Effect of urea and certain NPK fertilizers on the cereal cyst nematode, Heterodera avenae) on wheat. Saudi Jour. Biological Science, 21:191-196.

Andersen, K. and S. Andersen, 1982. Heterodera avenae: virulence and resistance. Pp. 272-285, in Cyst Nematods, eds: F. Lamberti and C-E. Taylor), Plenum Press, New York.

Anonymous, 2016. Agricultural statistics. Egyptian Ministry of Agriculture and Land Reclamation. Economic Affairs Sector.

Arrigoni, O., G. Zacheo, R. Arrigoni-Liso, T. Bleve-Zacheo and F. Lamberti, 1979. The role of ascorbic acid in the defense mechanism of plants to nematode attck. Pp.469-470. In: Root Knot Nnematodes, Meloidogyne species), Systematics, Biology and Control, F. Lambertic and CE. Taylor, eds) Academic Press, London New York, San Francesco.

Atiyeh, R.M., S. Lee, C.A. Edwards, N.Q. Arancon and J.D. Metzger, 2002. The influence of humic acids derived from earthworm- processed organic wastes on plant growth. Bioresource Technol., 84:7-14.

Baheti, B.L., M. Dodwadiya and S.S. Bhati, 2017. Eco-friendly management of maize cyst nematode, Heterodera zeae on sweet corn. Journal of Entomology and Zoology Studies, 5(6):989-993.

Baklawa, M., B. Niere and S. Massoud, 2012. Variation in reproduction and potential damage of Egyptian populations of Heterodera avenae on different wheat varieties. $31^{\text {st }}$ International European Society of Nematologists Symposium, 23-27 September, Adana, Turkey.

Bamel, V., K.K. Verma, D.C. Gupta, R.V. Singh et al., 2003): Effect of different fertilizers forms on Meloidogyne incognita infecting mungbean, Vigna radiaat. Proceedings of National Symposium on Biodiversity and Management of Nematodes in Cropping Systems for Sustainable Agriculture. Jaipure, India pp. 240-244.

Brown, R.H., 1982. The ecology and control of cereal cyst nematode, Heterodera avenae) in southern Australia. Journal of Nematology, 14, 433, Abstr.

Brown, R.H., 1987. Control strategies of low value crops, in : Principles and Practice of Nematode Control in Crops, R.H. Brown and B.R. Kerry, eds. Academic Press, New York, PP. 351-87.

CAB International, 1999. Crop Protection Compendium. Global Module, CD), Wallingford, UK.

Canellas, L.P. and F.L. Olivares, 2014. Physiological responses to humic substances as plant growth promoter. Chem. Biol. Technol. Agriculture, 1:1-11.

Canellas, L.P., F.L. Olivares, N.O. Aguiar, D.L. Jones, A. Nebbioso, P. Mazzei and A. Piccolo, 2015. Humic and fulvic acids as biostimulants in horticulture. Scientia Horticulture, 196:15-27.

Chen, Y., M. De Nobili and T. Aviad, 2004. Stimulatory effects of humic substances on plant growth. In: Magdoff F., Weil R.R., eds. Soil Organic Matter in Sustainable Agriculture. CRC Press, Boca Raton, FL.

Chitwood, D.J., 2002. Phytochemical based strategies for nematode control. Ann. Rev. Phytopathol., 40: $221-249$.

Christe J.R. and V.G. Perry, 1951. Removing nematodes from the soil. Proceeding of the Helminthological Society of Washington, 18: 106-108.

Cordeiro, F.C., C. Santa-Catarina, V. Silveria, and S.R. de Souza, 2011. Humic acid effect on catalase activity and the generation of reactive oxygen species in corn, Zea mays L.. Biosci. Biotechnol. Biochem., 75:70-74.

Cui, L., L. Sun, X. Gao, X. Song, X.M. Wang et al., 2016. The impact of resistant and susceptible wheat cultivars on the multiplication of Heterodera filipjevi and H.avenae in parasite-infested soil. Plant pathology, 65:1192-1199.

Dababat, A.A., G. Erginbaş -Orakci, H. Toktay, M. Imren, B. Akin, et al., 2014. Resistance in winter wheat to Heterodera filipjevi in Turkey. Turkish Journal of Agriculture Forestry, 38:180-186.

Dababat, A.A., M. Imren, G. Erginbaş-Orakci, S. Ashrafi, and E. Yavuzaslanoglu, 2015b. The importance and management strategies of cereal cyst mematode, Heterodera spp. In Turkey. Euphytica 202:173-188. 
Dababat, A.A. and H. Faurie, 2018. Nematode Parasites of Cereals. PP. 163-221. In: Plant Parasitic Nematodes in Subtropical and Tropical Agriculture. R.A. Sikora, D. Coyne, J. Hallmann, P. Timper, eds.) CABI, USDA, Tifton, Georgia, USA. $3^{\text {rd }}$ Edition.

D'Addabbo, T., S. Laquale, M. Perniola and V. Candido, 2019. Biostimulants for Plant Growth Promotion and Sustainable Management of Phytoparasitic Nematodes in Vegetable Crops. Agronomy 2019, 9, 616. www.mdpi.com/journal/agronomy.

Daneel, M.S., K. de. Jager, S. Dreyer, J. Dekker and J.P. Joubert, 2000. The influence of oxihumate on nematode control and on yield, Musa AAA, Cavendish sub group. Acta Horticulture, 540:441-452.

Dursun, A., I. Guvenc and M. Turan, 2002. Effects of different levels of humic acid on seedling growth and macro and micronutrient contents of tomato and eggplant. Acta Agrobotanica, 56:81-88.

Elekçioglu, I.H.; M. Avci, J. Nicol, K. Meyveci, N. Bolat, A. Yorgancilar et al., 2004. The use of crop rotation as means to control the cyst nematode under rainfed wheat production systems. 8-10 sept., $1^{\text {st }}$ National Plant Pathology Congress, Samsun, Turkey.

El-Ghamry, A.M., M. Kama, and K.M. Abd-Ghoneem, 2009. Amino and humic acids promote growth, yield and diseases resistance of faba bean cultivated in clayey soil. Aust. Jour. Basic Appl. Sciences, 3:731-739.

El-Sherif, A.G., A.R. Refaei, M.E. El-Nagar and H.M. Salem, 2008. Influence of Certain Animal Wastes, Urea and Oxamyl on Meloidogyne incognita Infecting Eggplant. Egypt. Jour. Agronematol., 6(1): 99-108.

FAO., 2012. GIEWS Country Brief on Egypt, Online) FOA. Available: http://www. foa.org/giews /countrybrief/country. jsp? Code=Egy.

Farahat, A.A., A.A. Al-Sayed and N.A. Mahfoud, 2010. Compost and other organic and inorganic fertilizers in the scope of the root-knot nematode reproduction and control. Egyptian J. Agronematology, 9(1): 18-29.

Fisher, J.M. and T.W Hancock, 1991. Population dynamics of Heterodera avenae Woll. in South Australia. Australian Journal of Agricultural Research, 42:53-68.

Gurner, P.S., A.J. Dube and J.M. Fisher, 1980. Chemical control of cereal cyst nematodes, Heterodera avenae) on wheat by a new low-volume Applicator .Nematologica, 26: 448-454.

Handa, D.K., R.L. Mathur and B.N. Mathur, 1975 publ. 1976. The effect of crop rotation and nematicides on the cereal cyst nematode Heterodera avenae and yield of wheat and barley. Indian Jour. Mycology and Plant Pathology, 5:20-21.

Hartz, T.K., and T.G. Bottoms, 2010. Humic substances generally infective in improving vegetable crop nutrient uptake or productivity. Hort. Science 45:906-910.

Hassan, H.M., 1999. Effect of some Antioxidants on the Response of Cucumber to Meloidogyne javancia Infection and Activity of the Plant. Egyptian Jour. Agronematology 3(1/2): 139-148.

Holgado, R. and D.H. Crump, 2003. First record on the occurrence of nematophagous fungi parasitizing cyst nematodes in Norway. International Journal of Nematdogy, 13:65-71.

Huebner, R.A., Rodriguez-Kabana R. and R.M. Patterson, 1983. Hemicellulosic waste and urea for control of plant - parasitic nematodes: effect on soil enzyme activities. Nematropica, 13:37-54.

Ibrahim, I.K.A., M.A. Rezk and A.A.M. Ibrahim, 1986. Occurrence of the cyst nematode Heterodera avenae, $H$. daverti and $H$. rosii in Northern Egypt.Journal of Nematology, 18(4):614 (Abstr.).

Ibrahim, D. S.S., A.H. Nour El-Deen, A.E. Khalil and F.A.M. Mostafa, 2013. Induction of systemic resistance in sugar beet infected with Meloidogyne incognita by humic acid, hydrogen peroxide, thiamine and two amino acids. Egyptian Jour. Agronematology, 12(1):22-41.

Ismail, A.E. and M.M. Mohamed, 2012. Nematicidal potentiality of some animal manures combined with urea against Meloidgyne arenaria and growth and productivity of sugarbeet under field conditions. Pakistan Jour. Nematol., 30(1):57-65.

Ismail, S., R.A. Sikora and R.P. Schuster, 2001. Occurrence and biodiversity of egg pathogenic fungi of Mediterranean cereal cyst nematode, Heterodera latipons. Communications in Agriculture and Applied Biological Sciences, 66:645-653.

Jifon, J.L. and G.E. Lester, 2009. Foliar potassium fertilization improves fruit quality of field-grow muskmelon on calcareous soils in south Texas. Jour. Sci. Food and Agriculture, 89:2452-2460. 
Jothi, G. and K. Poornima, 2017. Potassium humate for the management of root-knot nematode in tomato, Lycopersicon esculentum. Journal of Entomology and Zoology Studies, 5(4):646-648.

Kerry, B.R., D.H. Crump and L.A. Mullen, 1982b. Studies on the cereal cyst nematode, Heterodera avenae under continuous cereals, 1975-1978. II. Fungal parasitism of nematode females and eggs. Annals of Applied Biology, 100:489-499.

Kheir, A.M., A.A. Al-Sayed, and M.R. Saeed, 2009. Suppressive effects of inorganic fertilizers on $M$. incognita infecting soybean. Egyptian J. Agronematology, 7(1):9-19.

Korayemm, A.M. and M.M.M. Mohamed, 2015. Damage potential of Heterodera avenae on wheat growth and yield in relation to nitrogen fertilization in Egypt. Current Science International, 4(4): 515-519.

Korayem, A.M., H.M.S. El-Bassiony, A.A. Abd El-Monem and M.M.M. Mohamed, 2012. Physiological and biochemical changes in different sugar beet genotypes infected with root-knot nematode. Acta Physiol Plant, 34:1847-1861.

Lasserre, F., R. Rivoal and R. Cook, 1994. Interaction between Heterodera and Pratylenhus neglectus on wheat. Journal of Nematology, 26:336-344.

Maareg, M.F., F.M. Salem and A.M. Ebieda, 2000. Effect of certain organic and inorganic soil amendments on Meloidogyne javanica in sandy soil. Egyptian J. Agronematology, 4(1,2):8394.

Mackowiak, C.L., P. R. Grossl and B.G. Bugbee, 2001. Beneficial effects of humic acid on micronutrient availability to wheat. American Journal of soil Science Society, 56:1744-1750.

McBride, R.G., R.L. Mikkelsen, and K.R. Barker, 2000. The role of low molecular weight organic acids from decomposing rye in inhibiting root-knot nematode population in soil. Applied Soil Ecology, 15:243-251.

Mangat, B.P.S., D.C. Gupta, K. Ram, 1988. Effect of deep summer ploughing and in combination with aldicarb and time of application of aldicarb on cyst population of Heterodera avenae and subsequent effect on wheat yield. Indian Jour. Nematology, 18:345-346.

Mathur B.N., D.K. Handa, and G. Swarup, 1987. Effect of deep summer ploughing on the cereal cyst nematode Heterodera avenae and yield of wheat in Rajasthan, India. Indian Journal of Nematology, 17:292-295.

Mathur, B.N., G. Swarup, G.L. Sharma, and D. Handa, 1991. Effect of summer ploughing and nitrogen fertilizers on the cereal cyst nematode Heterodera avenae and yield of wheat. AfroAsian Journal of Nematology, 1:108-111.

McDonald, A.H. and J.M. Nicol, 2005. Nematode parasites of cereals, pp.131-191 in: Plant Parasitic Nematodes in Subtropical and Tropical Agriculture., Luc M., Sikora R.A. and Bridge J., eds. $\mathrm{CAB}$ International, Wallingford, UK, $2^{\text {nd }}$ edition.

Meagher, J.W., 1977. World dissemination of the cereal-cyst nematode, Heterodera avenae) and its potential as a pathogen of wheat. Journal of Nematology, 9(1):9-15.

Mojtahedi, H. and B.F. Lownsbery, 1976. The effect of ammonia-generating fertilizer on Criconemeodies xenoplax on pot cultures. Jour. Nematology. 8:306-309.

Moussa, F.F., S.A. Montasser, A.M. Korayem, A.B. Aboul-Sooud, M.M.A. Youssef, and M.M.M. Mohamed, 2006. Effect of certain organic amendments on Pratylenchus zeae, root-lesion nematode infesting sugarcane. Pakistan Jour. Nematology, 24(1):97-103.

Müller, J., 1992. Detection of pathotypes by assessing the virulence of Heterodera schachtii. Nematologica, 38:50-54.

Mylonas, V.A. and C.B. McCants, 1980. Effects of humic and fulvic acids on growth of tobacco. 2. Tobacco growth \& ion uptake. J. Plant Nutrition, 2:377-393.

Nardi, S., P. Carletti, D. Pizzeghello, and A. Muscolo, 2009. Biological activities of humic substances. In: Senesi N., Xing B., Huang P.M., eds. Biophysico-Chemcial Processes Involving Natural Nonliving Organic Matter in Environmental Systems, Vol. 2, Part 1. Wiley Hoboken. 305-340.

Nardi, S., D. Pizzeghello, A. Muscolo, and A. Vianello, 2002. Physiological effects of humic substances on higher plants. Soil Biology and Biochemistry, 34: 1527-1536.

Nicol, J.M., and R. Rivoal, 2008. Global knowledge and its application for the integrated control and management of nematodes on wheat. PP.251-294. In: Integrated Management and Biocontorl of 
Vegetable and Grain Crops Nematodes., A. Ciancio and K.G. Mukerji, eds. Springer, Dordrecht, The Netherlands.

Nombela, G., A. Navas and A. Bello, 1998. Effect of crop rotations of cereal with vetch and fallow on soil nematofauna in central Spain. Nematologica, 44: 63-80.

Osman, H.A., M.M.M. Mohamed, H. Abd-El-Khair, M.G. Dawood, 2014. Efficacy of three nitrogenous fertilizers urea, ammonium nitrate, ammonium sulfate with or without chitin on suppression of root-knot nematode, Meloidogyne incognita population infesting sunflower plant. A field study. Middle East Jour. Agric. Res., 3(4): 900-906.

Pankaj, Mishra S.D., and G.L. Sharma, 2002. Integrated management of Heterodera avenae infecting wheat. In R.V. Singh, S.C. Pankaj Dhawan and H.S. Gaur, eds. Pp.265-266. In Proceedings of National Symposium on Biodiversity and Management of Nematodes in Cropping Systems for Sustainable Agriculture. Jaipur, India.

Parandian, F. and S. Samavat, 2012. Effects of fulvic and humic acids on anthocyanin, soluble sugar, $\alpha$-amylase enzyme and some micronutrient in Lilium. Inter., Res. Jour. Applied Basic Sci., 3(5):924-929.

Pariyar, S.R., A.A. Dababat, S. Siddique, G. Erginbas-Orakci, A. Elashry, et al., 2016b. Identification and characterization of resistance to the cereal cyst nematode Heterodra filipjevi in winter wheat. Nematology, 18:377-402.

Pilanal, N. and M. Kaplan, 2003. Investigation of effects on nutrient uptake of humic acid application of different forms to strawberry plant. Journal of Plant Nutrition, 26(4):835-843.

Priya, B.N.V., K. Mahavishnan, D.S. Gurumurthy, H. Bindumadhava, P.U. Ambika, and N.K. Sharma, 2014. Fulvic Acid, FA) for Enhanced Nutrient Uptake and Growth: Insights from Biochemical and Genomic Studies. Journal of Crop Improvement, 28: 740-757.

Qiao, F., L. Luo, H. Peng, S. Luo, W. Huang, et al, 2016. Characterization of three novel fatty acidand retinoid - brinding protein genes, Ha- far- $1, \mathrm{Ha}-$ far -2 and $\mathrm{Hf}-$ far -1 ) from the cereal cyst nematodes Heterodera avenae and H. filipjevi. PLOS ONE 11, e 0160003.

Riggs, R.D., and D.P. Schmitt, 1988. Complete characterization of the race scheme for Heterodera glycines. Journal of Nematology, 20:392-95.

Riggs, R.D., and R.P. Schuster, 1998. Management, chapter 16, pp. 388-416), in The Cyst Nematodes, S.B. Sharma ed. Springer Science Business Meida Dordrecht.

Rivoal, R., and J.M. Nicol, 2009. Past research on the cereal cyst nematode complex and future needs. PP.3-10 in: Cereal Cysts Nematodes: Status, Research and Outlook, Riley I.T., Nicol J.M. and Dababat A.A., eds. CIMMYT, Ankara, Turkey.

Rodriguez-Kababna, R., 1986. Organic and inorganic nitrogen amendment to soil as nematode suppressants. Jour. Nemaotogy, 18(2):129-135.

Rodriguez-Kabana, R. and P.S. King, 1980. Use of mixtures of urea and blackstrap molasses for control of root-knot nematodes in soil. Nematropica 10:38-44.

Sangeetha, N., S. Palani and U. Ramar, 2006. Effect of lignite humic acid and fertilizers on the yield of onion and nutrient availability. $18^{\text {th }}$ World Congress of Soil Science, 9-15 Juli, 2006, Philadelphia, Pencilvania USA.

Saravanapriya, B., and S. Subramanian, 2007. Management of Meloidogyne incognita on tomato with humic acid and bioionocuants. Ann. Plant Prot. Sci. 15:195-197.

Seenivasan, N and S. Senthilnathan, 2018. Effect of humic aicd on Meloidogyne incognita, Kofoid and White) Chitwood infecting banana, Musa spp.) International Journal of Pest Management , 64(2): 110-118.

Seinhorst, J.W., and H. Den Ouden, 1966. An improvement of bijloo's method for determining egg content of Heterodera cysts. Nematologica, 12: 170-171.

Shahina, F., and M. A. Maqbool, 1991. Management of Heterodera zeae on corn and H. avenae on barey with Aldicarb and Carbofuran. Pakistan Journal of Nematology, 9:53-56.

Sharma, G.C. and M.L. Khan, 1995. Effect of NPK fertilizers on Meloidogyne incognita infestation and plant growth in tomato. Indian J. of Nematology, 25(2):147-149.

Shepherd, A.M., 1970. Extraction and estimation of Heterodera.PP.23-33.In:Laboratory Methods for Work with Plant and Soil Nematodes. Edited by J.P. Southey. Ministry of Agric.,Fisheries and Food,Technical Bulletin 2, London. 
Smiley, R.W., 2009. Occurrence, distribution and control of Heterodera avenae and H. filipjevi in the Western USA. Proceeding of the First Workshop of the International Cereal Cyst Nematode Initiative, Cereal Cyst Nematodes: Status, Research and Outlook. 21-23 October, 2009, Antalya, Turkey. P. 35-40.

Smiley, R.W. and J.M. Nicol, 2009. Nematodes which challenge global wheat production. PP. 171187. In: Wheat Science and Trade. B.F. Carver (ed. Wiley-Blackwell, Ames., Iowa.

Smiley, R.W., R.G. Whittaker, J.A. Gourlie, S.A. Easley and R.E. Ingham, 2005. Plant-parasitic nematodes associated with reduced wheat yield in Oregon. Journal of Nematology, 37,297-307.

Smiley, R.W., J.M. Marshall, J.A. Gourlie, T.C. Pauliz, S.L. Kandel et al., 2013. Spring wheat tolerance and resistance to Heterodera avenae in the Pacific Northwest. Plant Disease, 97: 590600.

Sun, Z., S. Xue, W. Liang and Y. Liu, 2004. Effects of different application rates of humic acid compound fertilizer on pepper and its mechanism of anti-senility and incremental yield. The journal of Applied Ecology, 15(1): 81-84.

Swarup, G., 1986. Investigations on wheat nematodes. Pp. 189-206. In: Twenty-five years of Coordinated Wheat Research 1961-86, eds J.P. Tandon and A.P. Sethi): Wheat Project Directorate, Indian Council of Agricultural Research, New Delhi.

Trifonova, Z., 2001. Effect of inorganic fertilizers and soil type on the growth of potato and reproduction of Globodera rostochiensis Woll. Macedonian Agric. Review, 48(1-2)57-60.

Trudgill, D.L., 1987. Effect of rates of a nematicide and fertilizer on the growth and yield of cultivars of potato which differ in their tolerance of damage by potato cyst namatodes, Globodera rostochiesis. Plant and Soil, 104:235-243.

Trudgill, D.L., B.R. Kerry and M.S. Phillips, 1992. Seminar: integrated control of nematodes, with particular reference to cyst and root knot nematodes.Nematologica, 38: 482-487.

Turkmen, O., A. Dursun, E. Turan and C. Erdinc, 2004. Calcium and humic acid affect seed germination, growth and nutrient content of tomato, Lycopersicon esculentum L.), seedlings under saline soil conditions. Acta Agriculturae Scandinavica, Section B., Soil and Pant Science, 54:168-174.

Turner S.T., and J.A. Rowe, 2006. Cyst Nematodes. In: Perry, R.N. and Moens M., eds. Plant Nematology. CAB International, Wallingford, UK, 91-120.

Wei C., H. Zheng, Q. Li, X. Lü, et al., 2012. Nitrogen addition regulates soil nematode community composition through ammonium suppression. PLOS ONE/ www.plosone.org, 7(8):e43384.

Xudan, X., 1986. The effect of foliar application of fulvic acid on water use, nutrient uptake and yield in wheat. Australian Jour. Agric. Research, 37:343-350.

Yadav, B.D., S.P. Bishnoi and R. Chand, 2002. Proceeding of the National Symposium on Biodiversity and Management of Nematodes in Cropping Systems for sustainable AgricultureNematology in Rajasthan at a glace. Department of Nematology, Rajasthan Agricultural Univ., Agric. Res. Station, Durgapura, Jaipur., 51 PP., India.

Yildirim, E., 2007. Foliar and soil fertilization of humic acid affect productivity and quality of tomatio.Acta Agriculturae Scandinavica Section B-Soil and Plant Science, 57:182-186.

Ye, X., A. Ling, B. Zhang, X. Liu, and G. Liu, 2009. Effect of humic acid fertilizer on soil properties and leaf quality of tobacco. Acta Agriculturae Boreali Sinica, 24: 170-173.

Yu, Y., J.H. Liu, A. Peng and Z.J. Wang, 1998. Effect of selenium and fulvic acid on the sugar metabolism in wheat seedings. Acta scientiae Circumstantiae, 18: 401-405.

Zhang, S., Y. Gan, B. Xu, and Y. Xue, 2014. The parasitic and lethal effects of Trichoderma longibrachiatum against Heterodera avenae. Biological Control, 72:1-8. 